\title{
CHD4 wt Allele
}

National Cancer Institute

\section{Source}

National Cancer Institute. CHD4 wt Allele. NCI Thesaurus. Code C128252.

Human CHD4 wild-type allele is located in the vicinity of $12 \mathrm{p} 13$ and is approximately $37 \mathrm{~kb}$ in length. This allele, which encodes chromodomain-helicase-DNA-binding protein 4, plays a role in DNA unwinding. 